\title{
Service Encounter and Customer Psychological Contract
}

\author{
Yan Ma \\ School of Economics \& Trade Qingdao Technological University, Qingdao 266520, China \\ E-mail: mayanmnk@163.com
}

Junye Deng

Qingdao Binhai University, Qingdao 266555, China

\author{
Received: May 19, 2012 \\ Accepted: June 27, $2012 \quad$ Online Published: June 30, 2012 \\ doi:10.5430/jbar.v1n1p75 \\ URL: http://dx.doi.org/10.5430/jbar.v1n1p75
}

\begin{abstract}
The high-quality service has become the first important factor in enterprise's survival and development. This research aims to probe into influences of service encounter to customer psychological contract, studying relationships between service encounter and psychological contract, service providers and customers. Method of the questionnaire was used to get information. The result indicates that good service scene and high-quality service have important effects on customers' behavior intention, thus producing improvement of customers' satisfaction and loyalty to the enterprises.
\end{abstract}

Keywords: Service encounter, Technology intervention service encounter, Service providers, Customer psychological contract

\section{Introduction}

As it is well known, customers are the source of enterprises' profits. How to retain customers and how to reduce loss of customers is naturally becoming an important problem to be solved. Reviewing existing research achievements, we can find that research of customer psychological made by Fan Xiucheng (2006) mentioned that service encounter quality was the source, satisfaction was the precondition and making degree of service loyalty is the crux. Increasingly perfect service and products related with service bring in different enjoyment and feeling for the world.

With the rapid changes of market context and economic globalization, life cycle of products has become shorter and market competitions have become fiercer. However, the reasons for satisfaction and loyalty have common points to different service enterprises. Firstly, meeting customers' needs; secondly, being concerned with customers actively; thirdly, service providers' appropriate reaction when the service system arises from problems. The three goals are made by service providers in the service encounter. Therefore, effective management service encounter is vital. Effective management not only makes providers please customers, and the most important, makes providers understand the ways to please customers and what behavior can please customers.

At present, the research on international service has become hotter and hotter(Lovelock,C. and Yip, G., 1996). The key elements of service encounter are different international backgrounds and behavior intention of customers. Different customers require different service tendencies, which basically have two kinds. One kind is that customers pay attention to the aspect of technology or results, which is a good-quality service, mainly referring to an aspect of service marketing (Sureshchandar, G., Rajendran, C. and Kamalanabhan, T. 2001). The other is that customers focus on the aspect of function or process, such as the aspect of service quality or service scene (Zhao, X., Yeung, J. and Zhou, Q. 2002). Customers evaluate service encounter from the two aspects mainly. Providing high-quality service is the key to enterprise's survival and success in a competitive context. Therefore, facing service encounter of different countries, to adopt the technology intervention service encounter and strengthen the psychological contract between service providers and customers are important developing ways of service enterprises. The psychological contract between service providers and customers is the best channel which helps customers experience service functions.

2. Technology Intervention and Service Encounter

As an important channel of service management, service encounter has been considered a miniature of total services. More and more tech-elements have been applied in service encounter, which have played an important role in service 
delivery.

Interactive research between encounter between customers and service providers was paid attention to be early. With getting rid of low technology, service comes into a hi-tech state; therefore, technology intervention service encounter was put forward. For example, introduction of concept of automatic service technology, customers can obtain service under the auxiliary of modern hi-tech equipment without the help of service providers. This kind of hi-tech service encounter reduces direct encounter between service providers and customers. The technology intervention service encounter means service providers deliver services to customers by hi-tech means and hi-tech equipment's complete service delivery process replacing previous provider interactions. Especially today, there are more and more customers, auto-services offer them more convenience, and also provide the tools to solve our barriers of service providers' language.

Technology intervention service encounter has had a large influence on customers' behavior intention. Customers can serve themselves in this way, and can make self-protection of service contents. Service providers can improve satisfaction of customers' service encounter and encounter quality with customers through high-technology. Because each customer gets consistent high-quality service, English notes of automatic service equipments provide great convenience for customers, especially facing customers in different countries. Technology of service providers is crux factor influencing service encounter. Consummate skill of service providers is very essential to customers, influencing service quality of customers' perception. Technology intervention service encounter solves the problem of differences in service technology of service providers, and can provide high-quality services for customers. System design of technology intervention service encounter is perfect and service process is reasonable, which is good to customers' perception of service quality, especially, providing same quality service for customers in different countries is necessary. Installation of automatic equipment provides safeguard for professional service technology, which is beneficial for customers' evaluations of service encounter.

\section{Psychological Contract between Service Providers and Customers}

Three themes of the service encounter are mainly customer, service providers and service entity context. Service encounter emphasizes on quality of service process (Bruce D.Keillor, Dale lewison. 2007). In the service process, some relationships exist: relationship between service providers and customers, relationship between customers and service enterprises and relationship between service providers and enterprises. Service providers are shaping key roles of each relationship in the service encounter. Interaction of providers is an important element influencing service quality. How service providers interact with customers, how service providers communicate enterprises and build a relationship between customers and service enterprises eventually are the importance of service encounter research. Service relationships mainly refer to communication between customers and services, giving or accepting things after forming relationships, including visible and invisible. The formation of psychological contract is a kind of social exchange among providers. Based on the theory of social exchange, the psychological contract exists in the exchange relationships. That customers and service providers can develop psychological contract is a hotspot in research. Long-range psychological contract can be developed between customers and service providers, making service providers try their best to serve customers and build their own customers group. High-quality service needs lots of contributions, which can win more loyal customers, who can recommend the enterprise to others, praise the enterprise and express their fond of it, and then they can pay for high-price goods and services gladly.

In this paper, the psychological contract between service providers and customers is mutual responsibilities and obligations perceived by each other. The customers' responsibilities for service providers mean that customers try to cooperate with service providers, respect labor of service providers, are satisfied with services provided badly and publicize its positive reputation. Meanwhile, service providers are also responsible for customers and keep a good and long relationship with customers. Service providers should respect customers, not judge them by appearance, teat them equally, have good attitude toward them, and respond and handle the reactions and requests of customers on time. The psychological contract between customers and service providers is an important performance of good or bad service encounter.

\section{Influence of Service Encounter to Customer Behavior Intention}

Service encounter is interactive moment between customers and service providers (service providers). In the process of service consumption, service encounter is an important factor influencing customers' evaluation of service quality, thus contributing to interaction of each other and two-way communication. In service context, professional knowledge of service providers and their friendly attitudes toward customers and good or bad customers' evaluation of service encounter mainly reflects in customer behavior intention. Service encounter is mainly evaluated from aspects of technology (result) and function (process), which are the crux of customers evaluating service encounter. 
About technological aspect, customers' perception of service is that result of customers influences customers' behavior intention directly (Sureshchandar, G., Rajendran, C. and Kamalanabhan, T. 2001). Technological aspect mainly means that technology of service providers is consummate, process of service being right, design of service meeting requirements of customers, making correct judgment of requests of customers and that is service results and quality perceived by customers in the process of service. Functional aspect mainly means service enterprises provide good service context and make customers perceive a highest quality service. Some books and magazines are provided during process of customers waiting, making them perceive that waiting time is short and services are good. During consumption of customers, providing comfortable and enjoyable music is also a good customer's function, which is perceived by customers during service consumptions. The insertion of providers' potential factors of depending on customers and design factors of service enterprises and popular elements of society will make customers perceive that the service encounter is successful and be willing to come to the enterprise to consume and accept services.

\section{Research Enlightenment}

Some new elements have been put forward in the fields of service encounter related. Enlightenment has been provided for service management of enterprises. If service administrators instruct and train service providers, improve their accomplishment, meet demands of customers and handle their requirements quickly, service quality perceived by customers in the service encounter will be improved. Friendly and polite service of service providers will improve satisfaction of customers. During the service encounter, if administrators can design enterprises' service context, improve the quality of air and music, take an importance to physical and mental health of customers and make customers complete their consumption and service in a comfortable context. The satisfaction of customers will be improved, which help to customers' re-buy and spread its reputation.

\section{References}

Bruce D.Keillor, Dale lewison. (2007). The service encounter in a multi-national context. Journal of Services Marketing, 2007-21(6)451-461.

Lovelock,C. and Yip, G.. (1996). Developing global strategies for service businesses. California Management Review, Vol. 38 No. 2, pp. 64-86.

Subramony, M., Beehr, T. and Johnson, C. (2004). Employee and customer perceptions of service quality Indian firm. Applied Psychology: An International Review, Vol. 53 No. 2, pp. 311-328. http://dx.doi.org/10.1111/j.1464-0597.2004.00173.x

Sureshchandar, G., Rajendran, C. and Kamalanabhan, T. (2001). Customer perceptions of service quality: a critique. Total Quality Management, Vol. 12 No. 1, pp. 111-25. http://dx.doi.org/10.1080/09544120020010138

Zhao, X., Yeung, J. and Zhou, Q. (2002). Competitive priorities of enterprises in mainland China. Total Quality

Management, Vol. 3 No. 3, pp. 285-301. http://dx.doi.org/10.1080/09544120220135174 